\title{
Cloning, Expression and Genetic Transformation of Sucrose Phosphate Synthase (SPS) Gene in SACCharum SPONTANeUm L.
}

\author{
YUn-Wei ZHANG*, YUn-ZHUAN ZHOU, HAI-BO Lu, DENG-YU ZhENG, \\ AND YAN-HUA HUANG \\ Department of Grassland Science, College of Animal Science and Technology, \\ China Agricultural University/National Energy R\&D Center for Biomass (NECB), \\ Beijing 100193, P. R. China
}

Received April 21, 2017; revision accepted July 10, 2017

\begin{abstract}
Sucrose phosphate synthase (SPS) is a key enzyme catalyzing sucrose metabolism in plants. In this study, we isolated the SPS cDNA from Saccharum spontaneum and designated as SsSPS (GenBank accession no. MF398541). The full-length of SsSPS cDNA was 4153-bp with an opening reading frame (ORF) of 3132 nucleotides, which encoded a 1043-amino acid protein. The nucleotide sequences alignment showed that it had $98 \%, 97 \%$ and $87 \%$ homology with S. officinarum, Setaria italica and Lolium perenne, respectively. Moreover, the SsSPS was detected to express in leaf and stem tissues of S. spontaneum and exhibited a predominant expression in the stem tissue. However, there was no significant difference in the expression level of SsSPS between young leaves and mature ones. Additionally, we generated transgenic S. spontaneum using Agrobacterium-mediated transformation. Our data will provide a valuable foundation for further study of the potential role of SPS in plants.
\end{abstract}

Keywords: Saccharum spontaneum L., SPS gene, cloning, expression, tissue culture, genetic transformation

\section{INTRODUCTION}

It has long been recognized that fossil energy is drying up around the world, which not only aggravates global warming but also it even causes wars because of its over-utilization. Likewise, there is high consumption of fossil fuels in our country. China has become the world's second largest oil consumer and the top third importing country (Xie et al., 2007). At present, the lack of energy has been a constraint factor on economic development in China, which may even be a threat to its national security (Li et al., 2007). Ethyl alcohol from sugarcane has been commercialized successfully as a biomass energy resource, but there is still a huge development prospect to develop substitution for sugarcane as a kind of biomass energy resource in China (Li et al., 2014).

Saccharum spontaneum L., which belongs to Saccharum, Gramineae, is a perennial herbaceous plant with developed rhizome and 1-2 meters height of stem as a promising biomass energy resource. Meanwhile, S. spontaneum has excellent resistance to various abiotic stresses, strong endurance under barren environment with high biomasses. Furthermore, S. spontaneum has a moderate level content of sucrose, indicating a tremendous potential value as a biomass energy resource by promoting its sucrose content using molecular breeding (Chang et al., 2010). However, the genetic engineering on the sucrose metabolic related pathway of the $S$. spontaneum, which is essential for acceleration of the breeding processing of energy grasses, has not yet been conducted.

There are three enzymes involved in the metabolism of sucrose in plants, among which sucrose phosphate synthase (SPS) is a key enzyme catalyzing the synthesis of sucrose (Huang et al., 2012). SPS was discovered in wheat for the first time, and then detected in rice and maize

\footnotetext{
* Corresponding author, email: zywei@cau.edu.cn
} 
(Hawker, 1971; Liu et al., 2005). Previous studies indicated that the activity of SPS had a positive correlation with accumulation of sucrose, and most (85\%) of total sugar was presented as a form of sucrose in stem of Sorghum bicolor (L.) Moench (Gnansounou et al., 2005; Yang et al., 2009). In general, the SPS-A gene was increasingly expressed along with the growth of S. bicolor, which was considered to be the most essential reason for sucrose accumulation. The high activities of SPS enzyme were also detected in other plants with high sucrose contents, such as sugar beet and tomato, etc. (Hesse et al., 1995; Sun and Wang, 2005). Recently, the research on cloning and expression of SPS gene has been fast developing. Klein et al. (1993) cloned the SPS gene and analyzed its expression level in root, petiole and leaf tissue of spinach finding that SPS was expressed in an organ-specific manner and predominantly localized in the leaf. Wang et al. (2013) found that SPS gene had the highest expression in flower and the lowest expression in leaf of Lycium barbarum $\mathrm{L}$. In our study, we got SPS cDNA sequence from $S$. spontaneum through homology-based cloning and analyzed the expression patterns of SPS gene in S. spontaneum. Furthermore, we optimized the tissue culture system of $S$. spontaneum and gained transgenic plants overexpressing SsSPS gene. Our study on SPS gene in S. spontaneum will help us to better understand the synthesis, regulation and metabolism of sucrose and lay the foundation for Agrobacterium-mediated transformation and further breeding of new varieties of $S$. spontaneum with high sucrose content.

\section{MATERIALS AND METHODS}

\section{PLANT MATERIALS AND GROWTH CONDITIONS}

Seeds of three wild germplasms (A1, A16 and A19) of S. spontaneum derived from Sichuan, all of which showed good comprehensive traits like relatively high biomass and upper secondary content of sucrose according to the data of Tang (2016), were grown in a greenhouse in Beijing $\left(39^{\circ} 28^{\prime}-41^{\circ} 05^{\prime} \mathrm{N}, 115^{\circ} 25^{\prime}-117^{\circ} 35^{\prime} \mathrm{E}\right)$. Total RNA was extracted from the leaves of S. spontaneum (A1) using the TRIzol reagent method (Invitrogen, Carlsbad, CA, USA), and used for gene cloning. For gene expression analysis, total RNA from young leaves, mature leaves and middle part of stems of S. spontaneum (A16, A19), which had grown for 5 months, were isolated. Meanwhile, the meristem of stem tip of A19 was surfacedisinfected with $75 \%$ alcohol and cut into small pieces $5 \mathrm{~mm}$ in length for callus induction. E. coli DH5 $\alpha$, Agrobacterium tumefaciens EHA105 and expression vector pCAMBIA-Ubi1301 were preserved in our laboratory for vector construction and transformation.

\section{MOLECULAR CLONING AND BIOINFORMATICS ANALYSIS}

Total RNA was extracted from leaves of S. spontaneum using the TRIzol reagent method and used for cDNA synthesis using a Transcript RT-PCR Kit (Tiangen Biotech Co., Ltd., China) with an oligo-dT primer. The cDNA was amplified using the primers (Forward: 5'-GGCTGGAGAACATGT CGTGGAGGAT-3'; Reverse: 5'-AGCGCAGTG CTT GAATTCTCATTGTC-3') designed from the highly conserved regions of SPS gene from other plant species. Based on the fragment, the gene-specific primers (5'-GCTGCACCTCCTGTGAAGGAGATTA-3'; 5'-TCCTAGCGAGGTTCCAGATCCTCCA-3') were designed to amplify the 3'-end and 5'-end of the SPS cDNA, respectively. The conserved sequences, 3 '-end and 5'-end sequences, were compared to find an overlap region, and the full-length cDNA was finally acquired after sequence assembly. Afterwards, the sequence similarities of both nucleotide and amino acid sequences were compared using basic local alignment search tool (BLAST) (http://blast.ncbi. nlm.nih.gov/Blast.cgi). Multiple sequences alignment analysis with previously identified SPS proteins from other six plant species was performed using DNAMAN software. Protein structures of SPS were predicted using ProtParam software (http://web. expasy.org/protparam/). Conserved Domain Search Service at NCBI was used for conserved domain predication (http://www.ncbi.nlm.nih.gov/Structure/ cdd/wrpsb.cgi).

\section{GENE EXPRESSION ANALYSIS}

The total RNA from stem and leaf of S. spontaneum were respectively isolated, and then used for reverse transcription using Takara PrimeScript ${ }^{\circledR}$ RT reagent kit with gDNA Eraser (TaKaRa, China). Primers of real-time PCR (qRT-PCR) were designed according to Ye et al. (2011). The 25S rRNA gene was used as an internal control (Yang et al., 2012). The sequence of gene-specific primers and internal reference gene were as follows: (SPS-F: 5>-TCTTCTCAAACCCCCGTAAGC-3〉, SPS-R: 5>-CAGTTCACGATGTTCACCAAATG-3〉; 25S rRNA-F: 5>-GCAGCCAAGCGTTCATAGC-3>, 25S rRNA-R: 5>-CCTATTGGTGGGTGAACAATCC3〉). ABI 7500 FAST Real-Time PCR System (Applied Biosystems, USA) was used for gene expression analysis. 
CALLUS INDUCTION AND TISSUE CULTURE

The meristem from stem tip of S. spontaneum was used as explant for callus induction. The meristems were sterilized by immersion in $75 \%(\mathrm{v} / \mathrm{v})$ alcohol for $1 \mathrm{~min}$ followed by $5 \%(\mathrm{v} / \mathrm{v})$ sodium hypochlorite for $1 \mathrm{~h}$ with gentle shaking. To optimize the process of callus induction, the sterilized explants were plated on diverse callus induction mediums which were different from each other in terms of 2,4-D concentration $(1,2,3,4 \mathrm{mg} / \mathrm{L})$. The callus initiation was cultivated at $25^{\circ} \mathrm{C}$ in the dark for 4 weeks. Each subculture was conducted on a subculture medium at $25^{\circ} \mathrm{C}$ in the dark. Finally, calluses were grown in MS medium $+1 \mathrm{mg} / \mathrm{mL} \mathrm{KT}+30 \mathrm{~g} / \mathrm{L}$ sucrose $+8 \mathrm{~g} / \mathrm{L}$ agar $+3 \mathrm{mg} / \mathrm{L} 2,4-\mathrm{D}$ at $25^{\circ} \mathrm{C}$ with $16 \mathrm{~h}$ light and $8 \mathrm{~h}$ dark for differentiation.

\section{VECTOR CONSTRUCTION AND TRANSFORMATION}

The ORF of SsSPS cDNA was amplified and inserted into the expression vector, pCAMBIAUBI1301. The resulting vector harboring a Hyg (hygromycin phosphotransferase), which was used as a selectable marker and an intron interrupted gus ( $\beta$-glucuronidase gene), was then transferred into Agrobacterium strain EHA105. Calluses derived from the meristem of stem tip (A19) were used for genetic transformation and transgenic plantlets were placed into rooting medium composed of MS medium $+2 \mathrm{mg} / \mathrm{L} \mathrm{NAA}+30 \mathrm{~g} / \mathrm{L}$ sucrose $+8 \mathrm{~g} / \mathrm{L}$ agar $+3 \mathrm{mg} / \mathrm{L} 2,4-\mathrm{D}$ at $25^{\circ} \mathrm{C}$ with $16 \mathrm{~h}$ light and $8 \mathrm{~h}$ dark. The detailed procedures of transformation, selection and regeneration were performed according to Zhu et al. (2006).

\section{RESULTS}

\section{CLONING AND BIOINFORMATICS ANALYSIS OF SSSPS}

In the present study, we first isolated the SPS cDNA from S. spontaneum. A 2500-bp cDNA fragment from $S$. spontaneum was amplified by homologous cloning (Fig. 1a). Based on the cDNA fragment, 5' RACE and 3' RACE were used to generate the cDNA ends sequence (Figs. 1b, 1c). A 4153-bp full-length cDNA was acquired after sequence assembly and confirmed by sequencing (Fig. 1d). The S. spontaneum SPS cDNA, which we named SsSPS, contained an open reading frame (ORF) of 3132 -bp encoding a 1043-amino acid protein. The deduced protein has a predicted molecular mass of $116.95 \mathrm{kDa}$.

The amino acid sequence of SsSPS was $95 \%$ identical to Saccharum officinarum (ABX59534.1), 90\% to Setaria italica (XP 004973187.1), $86 \%$ to Bambusa oldhamii (AĀR16190.1) and Lolium perenne (BAE80113.1), 85\% to Oryza brachyantha (XP_006659287.1) and 84\% to Brachypodium distāchyon (AAQ15106.1) (Table 1). Like other SPS amino acids, SsSPS harbored similar conserved motifs, including GT1-sucrose synthase and glycosyl transferase-GTB-typesuperfamily which corresponded to the process of sucrose synthesis and glycosyl transferring, respectively (Fig. 2a). Multiple alignment analysis of the SsSPS amino acids with 6 other SPSs (SsSPS, SiSPS, SoSPS, BdSPS, ObSPS, BoSPS and LpSPS) demonstrated a high sequence conservation (Fig. 2b).

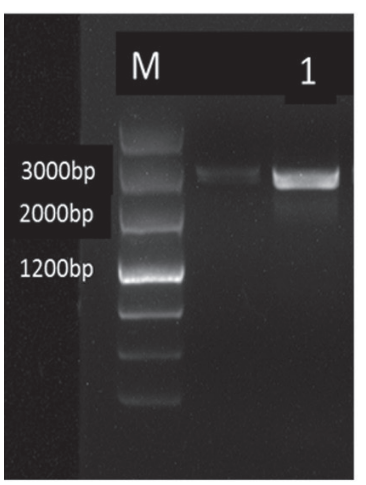

(a)

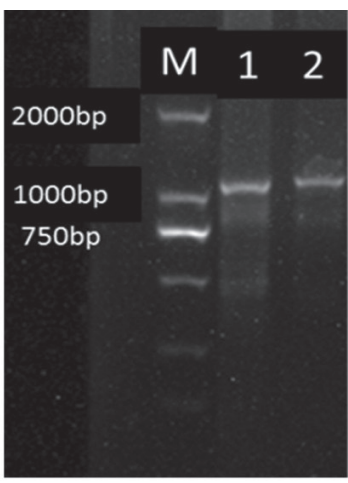

(b)

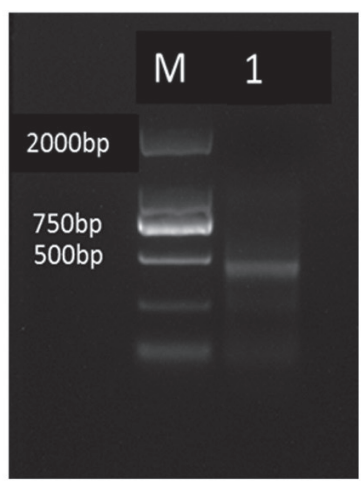

(C)

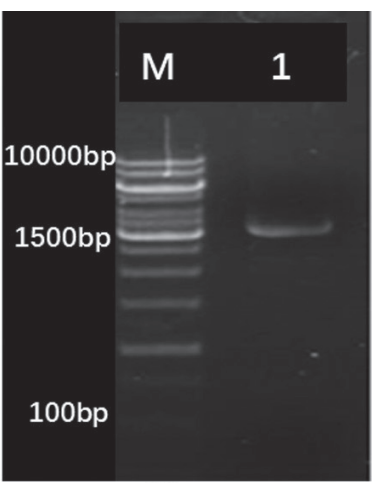

(d)

Fig. 1. Molecular cloning of SPS cDNA from S. spontaneum. (a) Amplification of core fragments. (b) Amplification of 3'RACE fragment. (c) Amplification of 5'RACE fragment. (d) Amplification of full-length cDNA. M - marker. 
TABLE 1. The blast result of nucleotide sequence (NS) and amino acid sequence (AS) of the SPS from S. spontaneum.

\begin{tabular}{lcccc}
\hline \hline $\begin{array}{c}\text { Similar species } \\
\text { (Blast) }\end{array}$ & $\begin{array}{c}\text { Query coverage (\%) } \\
\text { (NS, AS) }\end{array}$ & $\begin{array}{c}\text { E-value } \\
(\mathbf{N S}, \mathbf{A S})\end{array}$ & $\begin{array}{c}\text { Identity (\%) } \\
\text { (NS, AS) }\end{array}$ & $\begin{array}{c}\text { Accession NO. } \\
\text { (NS, AS) }\end{array}$ \\
\hline Saccharum officinarum & $97 \%, 99 \%$ & 0,0 & $98 \%, 95 \%$ & EU269038.1,ABX59534.1 \\
\hline Setaria italica & $97 \%, 99 \%$ & 0,0 & $97 \%, 90 \%$ & XM_004973130.1,XP_004973187.1 \\
\hline Bambusa oldhamii & $97 \%, 99 \%$ & 0,0 & $87 \%, 86 \%$ & AY445835.1,AAR16190.1 \\
\hline Lolium perenne & $96 \%, 99 \%$ & 0,0 & $87 \%, 86 \%$ & AB232784.1,BAE80113.1 \\
\hline Oryza brachyantha & $97 \%, 99 \%$ & 0,0 & $85 \%, 85 \%$ & XM_006659224.1,XP_006659287.1 \\
\hline Brachypodium distachyon & $97 \%, 94 \%$ & 0,0 & $85 \%, 84 \%$ & XM_003573633.2,AAQ15106.1 \\
\hline
\end{tabular}

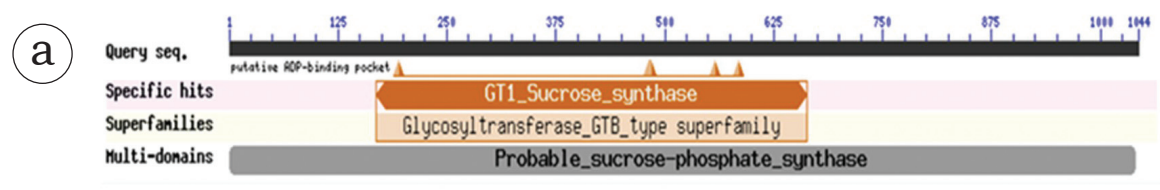

(b)

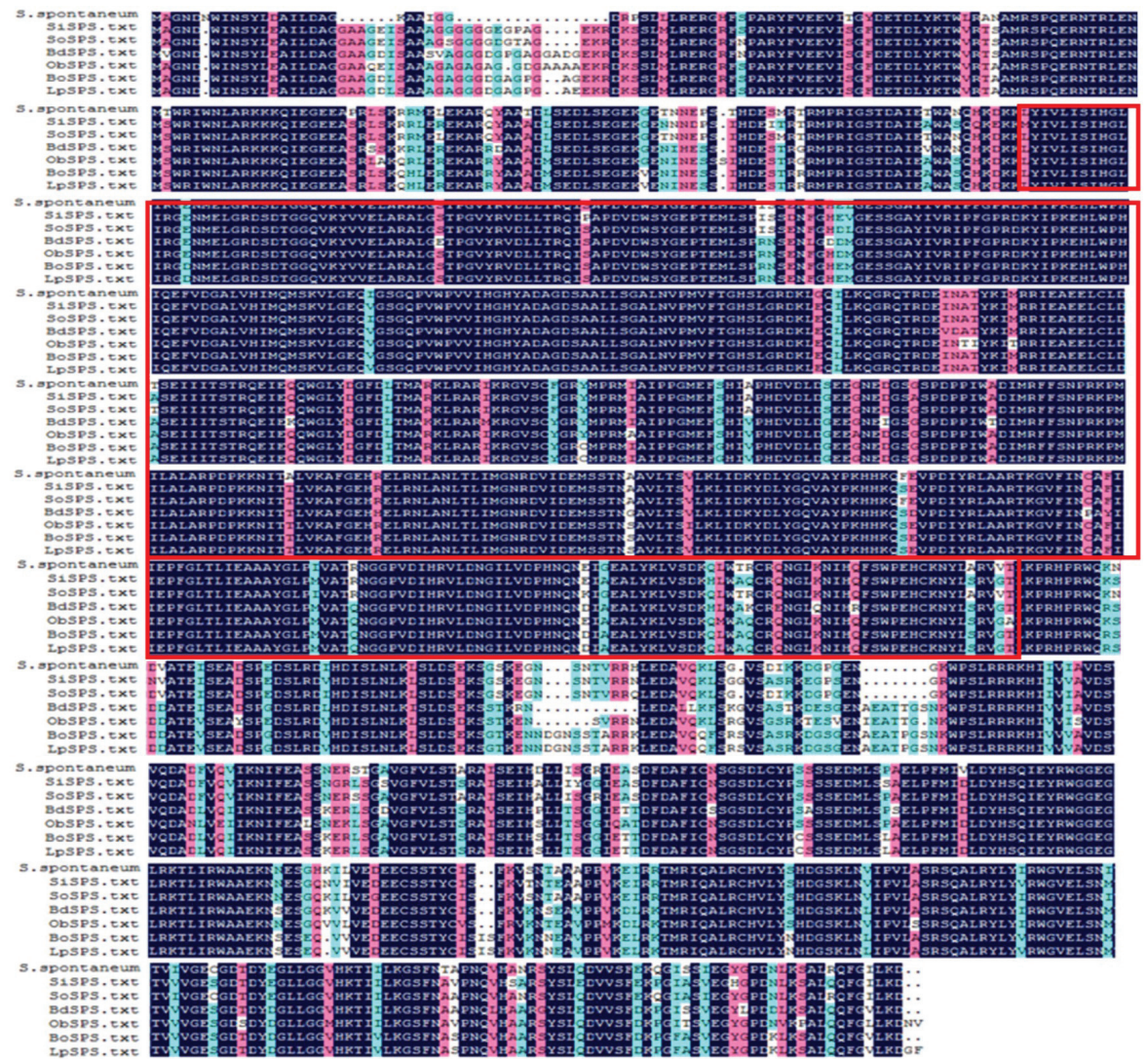

Fig. 2. (a) Conserved domain prediction of SsSPS. (b) Multiple alignment of the deduced amino acid sequences of SPS from different plant species. Conversed motifs for SsSPS are boxed. Protein IDs or accession numbers are as follows: Setaria italica SPS (XP 004973187.1), Saccharum officinarum SPS (ABX59534.1), Brachypodium distachyon SPS (AAQ15106.1), Oryza brachyantha SPS (XP_006659287.1), Bambusa oldhamii SPS (AAR16190.1) and Lolium perenne SPS (BAE80113.1). 


\section{EXPRESSION ANALYSIS OF SSSPS GENE}

In our study, the expression of SsSPS gene was studied in different tissues (stem and leaf) by qRTPCR. A single peak in the fluorescent melt curves of the amplified products of the target gene and 25S rRNA gene as a reference gene indicated that the primer pairs were specific (Fig. 3a). Based on that, we found that the SsSPS was expressed in both stem and leaf of S. spontaneum, and had a significantly higher expression level in the stem. Young leaves and mature leaves were not significantly different from each other in the expression level of SsSPS gene (Fig. 3b).
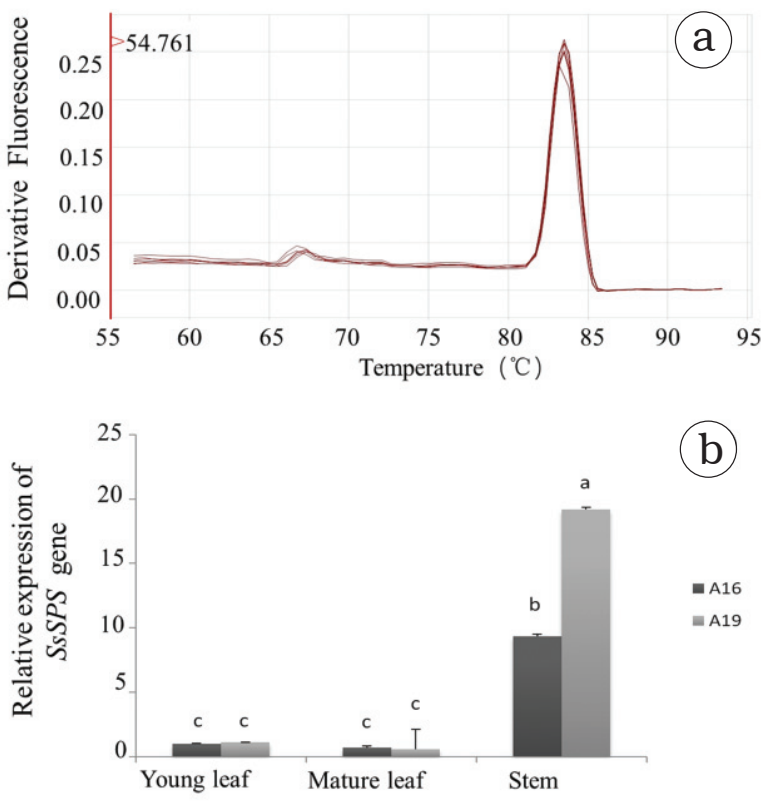

Fig. 3. (a) Fluorescent melt curves of $25 \mathrm{~S}$ rRNA as reference gene. (b) Expression patterns of SPS gene from leaf and stem tissues of $S$. spontaneum. Note: The data represent the mean $\pm \mathrm{S}$.E of three replicate samples. Columns with different letters indicate significant differences at $\mathrm{P}<0.05$.

\section{OPTIMIZATION OF TISSUE CULTURE SYSTEM}

To construct and optimize tissue culture system of S. spontaneum, the meristem from stem tip was used as explants and subjected to MS medium with different concentrations of 2,4-D (1 mg/L, $2 \mathrm{mg} / \mathrm{L}, 3 \mathrm{mg} / \mathrm{L}, 4 \mathrm{mg} / \mathrm{L}$ ). The callus of $3 \mathrm{mg} / \mathrm{L}$ and $4 \mathrm{mg} / \mathrm{L}$ 2,4-D could be induced with higher rate, better and quicker growth (Fig. 4a). Comparing the concentrations of $3 \mathrm{mg} / \mathrm{L}$ to $4 \mathrm{mg} / \mathrm{L} 2,4-\mathrm{D}$, the calluses were better produced in the subculture medium with $3 \mathrm{mg} / \mathrm{L}$ 2,4-D (Fig. 4b). Then the differentiation rate of callus with $3 \mathrm{mg} / \mathrm{L} 2,4-\mathrm{D}$ was correspondingly higher induced in the differential medium (Fig. 4c).
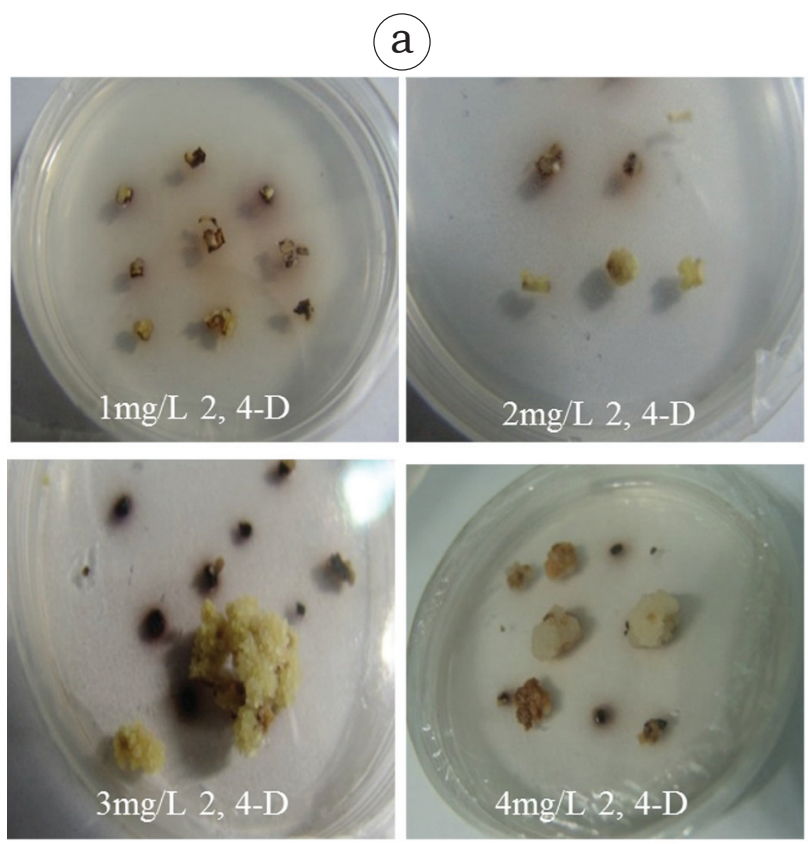

(b)
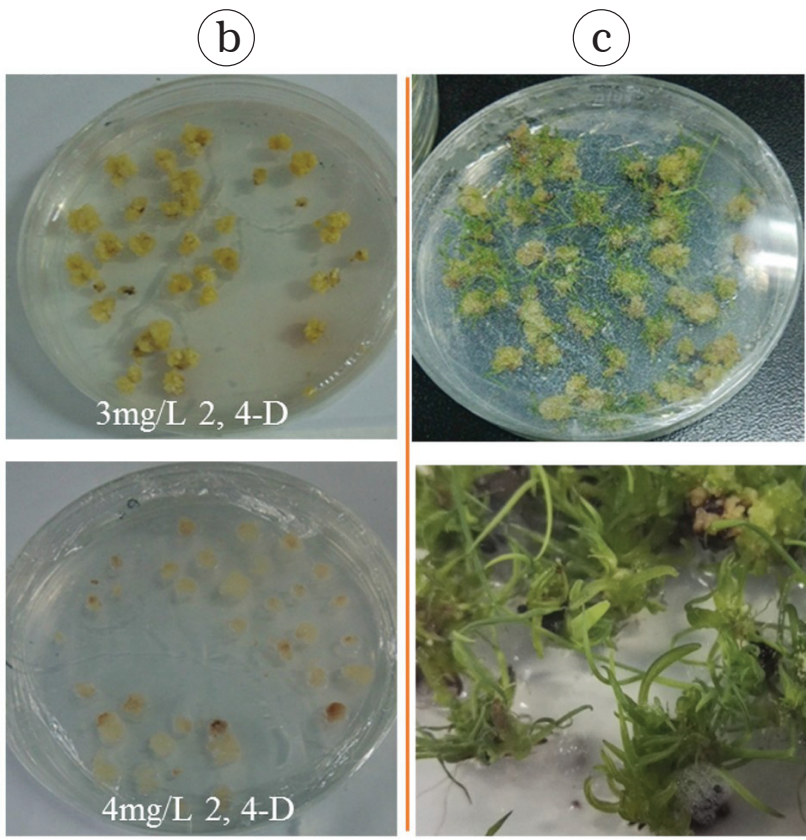

Fig. 4. Optimization of tissue culture system of $S$. spontaneum by different concentrations of 2,4-D. (a) Selection of optimum concentrations of 2,4-D for high efficiency of tissue culture system. (b) Callus from subculture medium. (c) Differentiation status from callus by $3 \mathrm{mg} / \mathrm{L} \mathrm{2,4-D.}$

\section{VECTOR CONSTRUCTION AND TRANSFORMATION}

Transgenic S. spontaneum plants expressing the SPS gene were generated by transforming $S$. spontaneum with the binary vector Ubi1301SsSPS. The vector carried the Hyg (hygromycin phosphotransferase gene) as a selectable marker 
and the transgene was constitutively expressed under the control of maize ubiquitin promoter and $35 \mathrm{~S}$ promoter (Fig. 5a). The procedure of the genetic transformation was based on the Agrobacterium-mediated method. The callus from MS induction medium with $3 \mathrm{mg} / \mathrm{L} \mathrm{2,4-D,}$ which had a better color and structure, was used for transformation (Fig. 5b). The callus generated green spots within 1 week. After 2 weeks of cultivation, the green spots on callus developed into kanamycin-resistant transgenic adventitious shoots with a high regeneration frequency (Fig. 5c). One month later, vigorous plantlets selected by $50 \mathrm{mg} / \mathrm{L}$ hyg B (hygromycin B) were generated from callus on the differentiation medium (Fig. 5d). The regenerated green shoots were rooted on MS medium supplemented with $50 \mathrm{mg} / \mathrm{L}$ hyg B for further selection (Fig. 5e).

\section{DISCUSSION}

\section{BIOINFORMATICS ANALYSIS OF SSSPS}

As sucrose-phosphate synthase (SPS) is a key enzyme catalyzing the synthesis of sucrose in plants, a study on it is definitely of importance for S. spontaneum as a quite potential and promising biomass energy resource, and so is the study on genes encoding it. Currently, the SPS gene has been cloned in many species, such as Spinacia oleracea, Citrus reticulata and Dendrocalamus sinicus (Liu and Li, 2003; Zhang et al., 2008). With the further in-depth research, molecular characteristics of SPS are believed to be crucial for playing a physiological role of regulating photosynthetic carbon flux into sucrose (Sawitri et al., 2016). A predicted molecular mass of $116.95 \mathrm{kDa}$ for SsSPS is similar to the molecular mass of SPS from Arabidopsis thaliana (117.32 kDa), Medicago sativa (117.89 kDa), Dendrocalamus oldhami (119.33 kDa) and Oncidium hybridum (118.67 kDa) (Bausher, 2002), which corresponds to Macrae et al. (2004) that plant SPSs have a molecular mass around $120 \mathrm{kDa}$. Previous studies suggested that SPS had an abundant genetic diversity, variation and was classified into four families in gramineae, including A, B, C and D (Huang et al., 2011; Xu et al., 2011). In addition, SPS genes from various families were significantly different on the nucleotide sequences other than the functional role (Liu et al., 2005). In the present study, nucleotide sequence alignment showed that SPS from S. spontaneum shared a high homology (98\%) with SPS-A family but presented a low homology (65\%) with SPS-B family of sugarcane. Therefore, it is suggested that SsSPS belonged to SPS-A family. Meanwhile, we found that there were two function domains, GTlsucrose-synthase and glycosyl transferase-GTBtype superfamily corresponding to the process of sucrose synthesis and glycosyl transfer which was the central region containing glycosyl transferase domain responsible for the catalytic function of SPS (Macrae et al., 2004). Similarly, studies have shown that SPS of maize also has two function domains

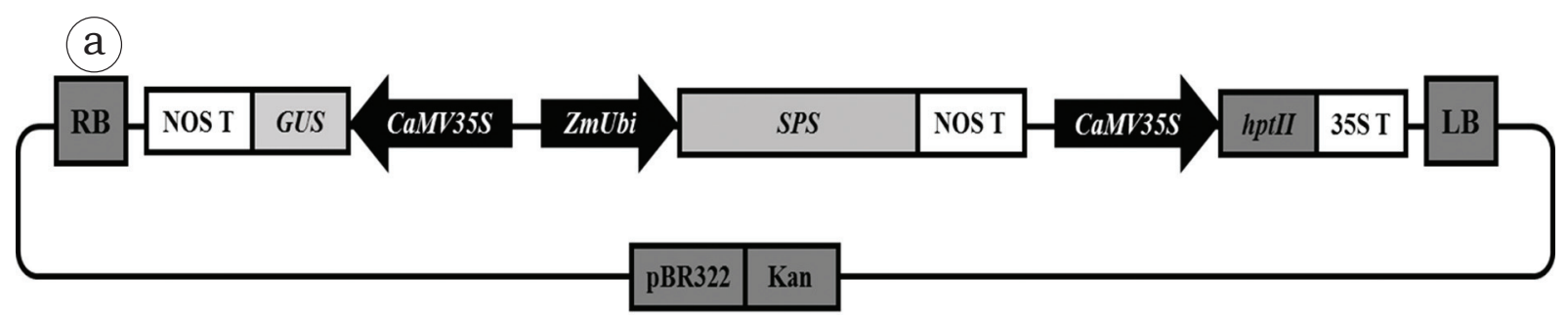

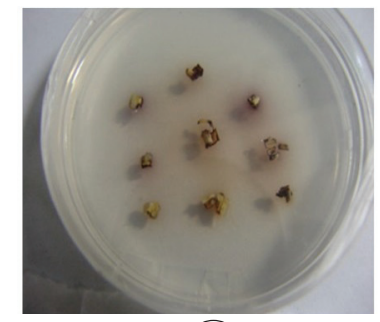

(b)

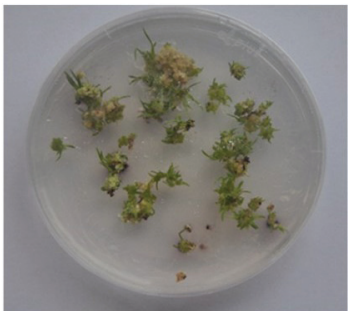

(c)

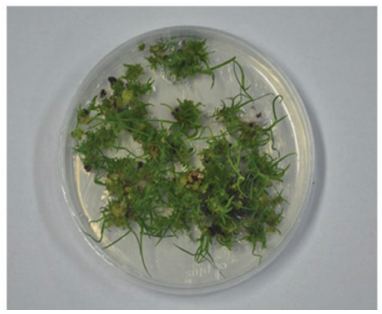

(d)

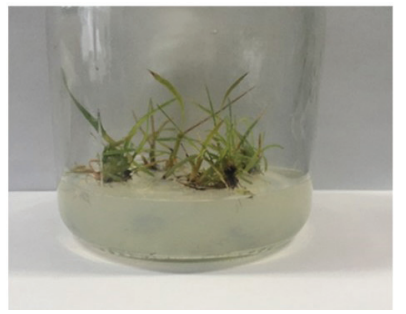

(e)

Fig. 5. Genetic transformation of sucrose phosphate synthase (SPS) gene from S. spontaneum. (a) Schematic diagram of vector conduction. (b) Callus from meristem on MS medium by $3 \mathrm{mg} / \mathrm{L} \mathrm{2,4-D}$. (c) Phenotype of callus for 2 weeks on differentiation medium. (d) Phenotype of callus for 1 month on differentiation medium. (e) Rooting culture of regeneration seedlings. 
(Lunn et al., 2000). The results of analyzing signal peptide and transmembrane domain of SPS gene in S. spontaneum showed that there was no transmembrane domain and signal peptide, suggesting that the whole peptide chain only played a role in the cytoplasm and did not enter subcellular organelle. These studies would provide an insight into molecular mechanism of SsSPS for affecting plant sucrose biosynthesis.

\section{EXPRESSION ANALYSIS OF SSSPS GENE}

Real-time PCR method, a common method to study gene expression at RNA level, was chosen to study the expression of SPS gene in different tissues based on some advantages like better specificity, higher sensitivity and so on (Mohamad et al., 2013). In this study, an organ-specific expression pattern of SsSPS gene was emphasized (Fig. 3b), which had also been reported in sugarcane (Ye et al., 2011) and sweet sorghum (Yang et al., 2009). Interestingly, SPS gene was predominantly expressed in tap root of sugar beet (Hesse et al., 1995), or fruits and flowers of Lycium barbarum (Wang et al., 2013). Given the above references, we could hypothesize that the tissue with a higher expression level of SPS gene presumably had higher sugar contents in plant. Combining the expression level of SsSPS gene with the data on sucrose content of S. spontaneum by Tang (2016), we found a relatively positive correlation between them, which was in agreement with findings of Komatsu et al. (1999) showing that sucrose gradually accumulated and eventually comprised about $65 \%$ of the total sugars in the mature citrus fruits where the expression of CitSPS1 and CitSPS2 genes rapidly increased during the mature stage in the edible tissue. Otherwise, the expression pattern of SPS at different development stages of plants was also explored. Yu et al. (2007) analyzed the developmental stages-specific expression of SPS gene in melon fruit by Northern blot and found that the expression of SPS gene began to be present 25 days after pollination, and the expression level increased along with the ripening degree of fruit. Li et al. (2015) found that the expression level of cacao SPS gene showed a rising trend with the development of leaves and buds. All of this evidence indicates that the expression of SPS gene has spatial and temporal specificity and also depends on plant species.

\section{OPTIMIZATION OF TISSUE CULTURE SYSTEM AND TRANSFORMATION}

In order to establish an efficient Agrobateriummediated transformation system for S. spontaneum, we optimized tissue culture system by selecting most suitable concentration of 2,4-D in the basal induction medium. We then used this culture system in a callus-based $S$. spontaneum transformation system. However, the browning occurring in calluses of our study resulted in a low product rate during the process of callus induction. According to previous studies, the phenomenon of browning was generally attributed to polyphenol oxidase (PPO) acting on natural substrate phenolic compounds, which is one of the three major problems in tissue culture (Li et al., 2005). Additionally, some studies found that medium with glucose as a carbon source could effectively prevent browning, followed by maltose, sucrose worst (Yan et al., 2003). The reason for browning in this experiment may be related to medium with sucrose. Our result exhibited that higher concentration of 2,4-D in this experiment had a higher rate of product and less browning compared to the result caused by low concentrations of 2,4-D group. Previous studies also demonstrate that the auxin 2,4-D or IAA can delay the synthesis of phenol and reduce browning (Xu et al., 1997). Therefore, the $3 \mathrm{mg} / \mathrm{L} 2,4-\mathrm{D}$ was an optimal hormone concentration for callus induction; whereas rooting efficiency was not as good as we had expected on the rooting medium in our study, which could be caused by explant types, strains of Agrobacterium and also various conditions of tissue culture. Many studies have been conducted to improve the capacity of plantlet regeneration by optimizing the factors of the regeneration medium, especially PGRs (Zhao et al., 2011). Also, there are still a lot of factors like plant genotype and selection marker genes, influencing the accomplishment in S. spontaneum transformation. In our view, the main reason for the low success rate of transformation in S. spontaneum may be largely due to the technical immaturity of tissue culture and transformation in S. spontaneum for which there are few cases reported.

\section{CONCLUSION}

We successfully cloned the full-length cDNA of a SPS ortholog with 5'UTR and 3'UTR, which encoded sucrose phosphate synthase in S. spontaneum. Bioinformatics analysis of SsSPS indicated that it was a member of the SPS-A gene family. Expression analysis of SsSPS gene by qRTPCR exhibited a predominant expression in the stem tissue. $3 \mathrm{mg} / \mathrm{L} 2,4-\mathrm{D}$ was more suitable to construct and optimize the tissue culture system of S. spontaneum when the meristem from stem tip was used as explants. Our work serves as a foundation for further breeding process of S. spontaneum with a high sucrose content. 


\section{AUTHORS' CONTRIBUTIONS}

ZYW designed experiments and was involved in paper revision. ZYZ, LHB, ZDY conducted experiments and collected data. ZYZ wrote the first draft of manuscript. HYH gave assistance in performing experiments and draft of manuscript. The authors declare no conflict of interest.

\section{ACKNOWLEDGEMENTS}

Funding for this work was provided by the Ministry of Science and Technology, China (2014BAD23B03 - 02), the National Natural Science Foundation of China (31272493).

\section{REFERENCES}

BAUSHER M. 2002. Isolation and characterization of the sucrose synthase promoter from Citrus sinensis L. Osbeck CV. Valencia in transgenic tobacco. Journal of Biological Chemistry 277: 32157-32164.

Chang D, Bai SQ, Yan JJ, Liang XZ, Gan YM, Yang FY, and Zhang YW. 2010. Advances in research germplasm resources of Saccharum spontaneum L. as energy potential plant. Academic Seminar of Youth Work Committee of China Grassland Society, 11 September 2010, 642-648. Shanghai.

Gnansounou E, Dauriat A, and Wyman CE. 2005. Refining sweet sorghum to ethanol and sugar: economic trade-offs in the context of North China. Bioresource Technology 96: 985-1002.

HAWKER JS. 1971. Enzymes concerned with sucrose synthesis and transformations in seeds of maize, broad bean and castor bean. Phytochemistry 10: 2313-2322.

Hesse H, Sonnewald U, and Willmitzer L. 1995. Cloning and expression analysis of sucrose-phosphate synthase from sugar beet (Beta vulgaris L.). Molecular Genetics and Genomics 247: 515-520.

Huang DL, FANG FX, Li T, Li SX, LiaO $Q$ and Li YR. 2011. Cloning of sucrose phosphate synthase gene (sofSPSa) from sugarcane and construction of its sense and antisense plant expression vector. Journal of Agricultural Biotechnology 19: 624-633.

Huang DL, Li SX, Liao Q, Gin CX, Lin L, Fang FX, and Li YR. 2012. Advances on sucrose phosphate synthase in plants. China Biotechnology 32: 109-119.

KLEIN RR, CRAFTs-BrandNer SJ, and SalvucCi ME. 1993. Cloning and developmental expression of the sucrose-phosphate-synthase gene from spinach. Planta 190: 498-510.

Komatsu A, Takanokura, Moriguchi T, Omura M, and AKIHama T. 1999. Differential expression of three sucrose-phosphate synthase isoforms during sucrose accumulation in citrus fruits (Citrus unshiu Marc.). Plant Science 140: 169-178.

Li FL, Hu GF and Hu BZ. 2005. Study on tissue culture and plant regeneration of the inflorescence in eight kinds color of Saliva splendens. Biotechnology 15: 71-73.
Li FP, Qin XW, Wu BD, Zhao XZ, Wang H, Zhu ZH and Lai JX. 2015. Phylogeny and expression profile of the sucrose phosphate synthase gene family in cacao (Theobroma cacao L.). Chinese Journal of Tropical Crops 36: 1608-1613.

LI JB, HE LL, and Li FS. 2007. Analysis of advantage and outlook on sugarcane as energy-crop. Chinese Agricultural Science Bulletin 23: 427-433.

Li Y, Li QW, DENG HH, QI YW, and Wu JY. 2014. General situation of energy plant and the cultivation of energy type sugarcane and Erianthus arundinaceus progeny prospect in China. Sugarcane and Canesugar 2014: 51-58.

Liu LX, SHEn FF, Lu HQ, HAN QD, and LiU YG. 2005. Research advance on sucrose phosphate synthase in sucrose metabolism. Molecular Plant Breeding 3: 275-281.

LiU YZ, and Li DG. 2003. Sugar accumulation and changes of sucrose-metabolizing enzyme activities in citrus fruit. Acta Horticulturae Sinica 30: 457-459.

Lunn JE, Ashton AR, Hatch MD, and Heldt HW. 2000. Purification, molecular cloning, and sequence analysis of sucrose-6F-phosphate phosphohydrolase from plants. Proceedings of the National Academy of Sciences of the U.S.A. 97: 12914-12919.

Macrae EA, Quick WP, Buchner P, Foyer CH, Furbank RT, and LUNN JE. 2004. Evolution and function of the sucrosephosphate synthase gene families in wheat and other grasses. Plant Physiology 135: 1753-1764.

Mohamad NA, Sheikha AFE, Mustafa S, and Mokhtar NFK. 2013. Comparison of gene nature used in real-time PCR for porcine identification and quantification: a review. Food Research International 50: 330-338.

Sawitri WD, Narita H, Ishizaka-IKeda E, Sugiharto B, Hase T, and NAKagawa A. 2016. Purification and characterization of recombinant sugarcane sucrose phosphate synthase expressed in E.coli and insect Sf9 cells: an importance of the N-terminal domain for an allosteric regulatory property. Journal of Biochemistry 159: 599-607.

SuB LP, and WANG XF. 2005. Cloning and sequencing of tomato fruit sucrose phosphate synthase gene. Shandong Agricultural Sciences 2005: 8-11.

TANG HG. 2016. Expression analysis of the key enzymes and their regulatory genes related to sucrose metabolism in Saccharum spontaneum L. M.D. disseration, China Agricultural University, Beijing.

WANG LJ, Ding XZ, WANG YC, and Li X. 2013. Cloning and tissue expression analysis of sucrose phosphate synthase gene from Lycium barbarum L. Acta Botanica BorealiOccidentalia Sinica 33: 1516-1520.

XIE GH, Guo XQ, Wang X, Ding RE, Lin HU, and Cheng X. 2007. An overview and perspectives of energy crop resources. Resources Science 29: 74-80.

Xu LP, QUE YX, and Su YC. 2011. Genetic diversity among sugarcane genotypes based on polymorphisms in sucrose metabolism genes. Scientia Agricultura Sinica 44: 1788-1797.

Xu ZB, Fu ZS, Yuan YP, Du J, Zhang XH, Tian LG, Jia YF, and Mu QH. 1997. Browning phenomenon in plant tissue culture. Rain Fed Crops 1997: 55-56.

Yan G, Zhang W, Zhang Y, Zhang YS, Song A, Hou J, Cheng X, and ZHANG L. 2003. Study of tissue culture techniques on depoison test-tube-plantlet of Elaeagnus mollis. Acta Botanica Boreali-Occidentalia Sinica 23: 1297-1303. 
Yang CF, Huang CM, Pan YQ, Wei YW, Deng ZN, Gin XM, and LI YR. 2012. Preliminary studies on expression of sucrose-phosphate synthase III gene in sugarcane. Journal of Southern Agriculture 43: 723-726.

Yang M, Liu LY, Wang B, Chang JH, and Liu GZ. 2009. Correlation analysis of sugar accumulation and SPS expression in sweet sorghum (Sorghum bicolor L. Moench) stems. Scientia Agricultura Sinica 42: 85-92.

Ye BY, Qiu S, Zhou P, SONG XM, Chen YQ and Chen RK. 2011. Cloning and expression analysis of sucrose-phosphate synthase II gene from sugarcane. Chinese Journal of Applied and Environmental Biology 17: 673-677.

YU XY, FAN JD, and HE QW. 2007. Cloning and expression analysis of a sucrose phosphate synthase cDNA fragment in melon fruit. Acta Horticulturae Sinica 34: 205-208.
ZHANG SZ, WANG Y and LIU XZ. 2008. Isolation and cloning of sucrose phosphate synthase gene (SPS) from Dendrocalamus sinicus. Journal of Southwest Forestry College 28: $48-50+56$.

ZHAO WN, ZHENG SS, and LiNG HQ. 2011. An efficient regeneration system and Agrobacterium-mediated transformation of Chinese upland rice cultivar Handao 297. Plant Cell, Tissue and Organ Culture 106: 475-483.

ZHU JH, QUAN JL, and HE YK. 2006. Studies on the transformation of plasmid prok II into Agrobacterium tumefaciens LBA4404 and C58C1. Journal of Northwest SciTech University of Agriculture and Forestry (Natural Science Edition) 126: 369-382. 